\title{
Musica Universalis or the Music of the Spheres ${ }^{\star}$
}

\author{
Jean-Pierre Birat ${ }^{*}$ \\ IF Steelman, Semécourt, France
}

Received: 6 January 2018 / Accepted: 9 March 2018

\begin{abstract}
The Music of the Spheres was a model of the universe proposed by Pythagoras and Aristotle, which explained cosmology in terms of spheres to which the sun, the moon and the planets were pinned, while their motion was driven by something akin to music. Modern thinking, related to ecology and industrial ecology, has metaphorically breathed life back into this old model by speaking about spheres again: biosphere, geosphere, anthroposphere, technosphere, hydrosphere, cryosphere, atmosphere, etc. Sustainable development also speaks about its three pillars (economy, environment, society) represented in a Venn diagram as intersecting circles (or spheres). All these models differ from the models of physicists, as they are more conceptual diagrams than a representation of the world as it is. Thus, they remind us of the old Music of the Spheres model. They also stress connections, exchanges, equilibria between the spheres - or the lack of them-, like Pythagoras' music. The presentation will discuss these various approaches, see how they match to some extent, but also how they do not show a perfect fit. Analyzing what happens at the boundaries of the spheres, where they overlap or penetrate into each other, is a powerful way to analyze the connection between technology, society, life and ecosystems. It can also help discuss pollution, ecotoxicology and explore global solutions.
\end{abstract}

Keywords: music of the Spheres / Musica Universalis / three pillars of sustainability / spheres of ecology / interaction between spheres

Résumé. La musique ou l'harmonie des sphères. La musique des sphères est un modèle du monde proposé par Pythagore et Aristote, qui expliquait la cosmologie en termes de sphères dans le ciel, sur lesquelles étaient fixées le soleil, la lune, les planètes et les étoiles fixes et dont le mouvement était réglé par un mécanisme semblable à la musique. La pensée moderne sur l'écologie et l'écologie industrielle a redonné vie métaphoriquement à ce modèle en parlant à nouveau de sphères : la biosphère, la géosphère, l'anthroposphère, la technosphère, l'hydrosphère, la cryosphère, l'atmosphère, etc. Le développement durable parle aussi de ses trois piliers (l'économie, l'environnement et la société) qui sont représentés dans un diagramme de Venn comme trois cercles (sphères) qui se coupent. Ces modèles diffèrent tous de ceux que propose la Physique, car ils représentent plus une vision conceptuelle du monde qu'une description factuelle de la façon dont il fonctionne. Par conséquent, ils font écho au vieux modèle de la musique des sphères. Eux aussi insistent sur les relations, les échanges et les équilibres qui règnent entre ces sphères ou qui en sont absents - un peu comme la musique de Pythagore. L'article décrit ces approches très différentes et s'interroge sur leurs similarités ou au contraire sur leurs décalages. Une façon puissante d'analyser les rapports entre la technologie, la société, la vie et les écosystèmes est d'analyser ce qui se passe aux frontières de ces différentes sphères, comment elles se frôlent, se superposent en partie ou s'interpénètrent. Cela permet aussi de discuter des questions de pollution, d'écotoxocologie et de recherche des solutions globales à ces questions.

Mots clés: musique des sphères / harmonie des sphères / les piliers du développement durable / les sphères de l'écologie / l'interaction entre les sphères

\section{Introduction: Musica Universalis}

Understanding how the world functions has been a universal endeavor of mankind for as long as historians

\footnotetext{
$\star$ This article was given as a keynote lecture at the EMERC 2017 (First International Conference on Energy and Material Efficiency), organized by ISIJ in Kobe, Japan, 11-13 October, 2017.

* e-mail: jean-pierre.birat@ifsteelman.eu
}

and paleoanthropologists have been able to peek into the past. The world includes "nature", people and their activities conducted with the artifacts that they have built-what has been traditionally called "civilization". Questions like what are the sun, the stars, the wind, rain, a rainbow, life, etc., which started up as religious questions and moved on to philosophy and metaphysics and then to science, physics or biology, call for answers, which, today, are provided by scientists of all kinds, but also by writers, 
novelists, poets, or other artists. Note also that all of these interact.

Religions have probably proposed the first global models of the world and, today, many people still look for answers in religious books, the Bible, the Coran, the Pali Tipika or other sacred texts. Religions have inspired works of art, like the ceiling of the Sistine Chapel, in the Vatican, which displays Genesis' myth of creation painted by Michelangelo and perpetrating the Bible model of the temporality of Art.

Philosophers took over the role of explaining the world from priests, at the same time, in Greece and in China. Pythagoras (ca. 580-495 BCE) and Aristotle (384-322 BCE) [1] thus proposed a model of the world, actually of the universe, which has been remembered as Musica Universalis, the Music of the Spheres or the Harmony of the Spheres - the latter expression stressing the relationship between the spheres rather than the physical sounds themselves. The concept started from the understanding that the cords of a musical instrument such as the lyre (cf. Fig. 1) vibrate and thus produce sounds, the pitch of which is directly related to their length: this was the first physical law that connected the physical world with the abstract world of numbers by establishing a quantitative relationship between sound frequency and cord length. Then, stunned by the novelty of this discovery, people started to wonder if this relationship did not have a broader meaning and if it did not explain more overwhelming phenomena, like the motion of planets in their circular orbs in the sky (cf. Appendix 1 and Fig. 2). The concept emerged slowly, thus not explicitly in Pythagoras' writings, but rather in those of Aristotle and of his followers: the connection was metaphoric and intuitive, based on the fact that there were 7 planets known at that time, like there were 7 cords on a lyre and 7 musical notes in the scale used to "write" music. Some interpretations were actually positing that the planets made music in their voyage through the sky, except that this music could not be heard from Earth; very sophisticated assumptions were made as to the notes which were produced by the planets, the Sun and the Moon. But others were more critical and even skeptical and they favored the metaphorical approach.

This was an attempt at connecting various realms of human knowledge, an interdisciplinary endeavor as we would say today, and to establish a mirror relationship between the world of people and abstract ideas and the world of nature.

Modern science has pushed very far the connection between mathematics and nature, physical sciences, but also life sciences and even social sciences: numerical simulations and mathematical models are present almost everywhere today but also a different kind of connection with numbers, artificial intelligence and deep machine learning [2]. Modern astronomy and cosmology describe the universe in ways that are far from the vision of Aristotle, but physical laws, expressed by numbers and making reference to geometrical concepts, from Kepler's laws to General Relativity, exhibit a continuity with Greek philosophy, conceptually if not in details [3]. New physical theories, like String or Brane Theory, connect even more

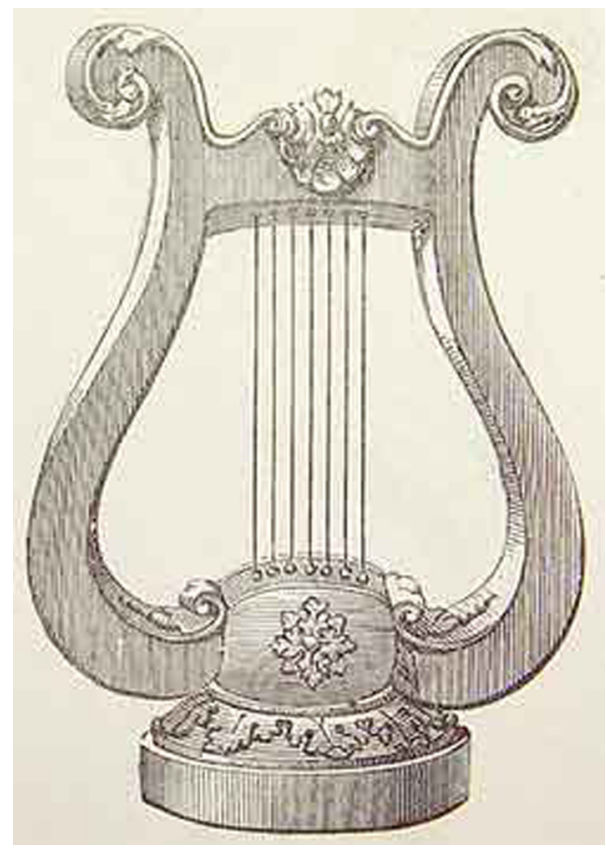

Fig. 1. The Greek lyre, in its sev-en-cord, most common version.

Fig 1. La lyre grecque, dans sa version la plus courante, à sept cordes.

with the Greeks' vision of the $5^{\text {th }}$ century BCE: strings are back at the heart of physics, even if people do not directly mention the Harmony of the Spheres.

Astronomers record signals from space, which can be translated into sounds; NASA has published recordings of such signals: it cannot exactly be called the music of the Spheres but certainly the Music of the Planets and of the Stars ${ }^{1}$, another twist of the expression that we are discussing here.

The Harmony of the Spheres theory, or a concept close to it, has survived in Cognitive Science to explain the response of the human brain to music - as opposed to the response to language. Researchers today have abandoned the idea that music is actually attune to the inner working mechanisms of the brain in all its complexity but seem to privilege the fact that the brain is decoding music either through its general pathways or through specifically dedicated regions in the brain [4], thus a modest impersonation of Musica Universalis.

A metaphor is a rhetorical device used extensively to propose representations of the world. From religions, myths and early philosophy to modern science, which relies heavily on modeling, the metaphor mediates between reality and its representation. Modern models used in science can also be described as metaphors [5]. Paul Ricoeur probably published one of the most profound philosophical study of the metaphor [6]. He explains that the metaphor can be purely rhetorical, thus a formal shift in the use of a word, but if one steps beyond semiotics and into semantics,

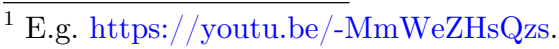




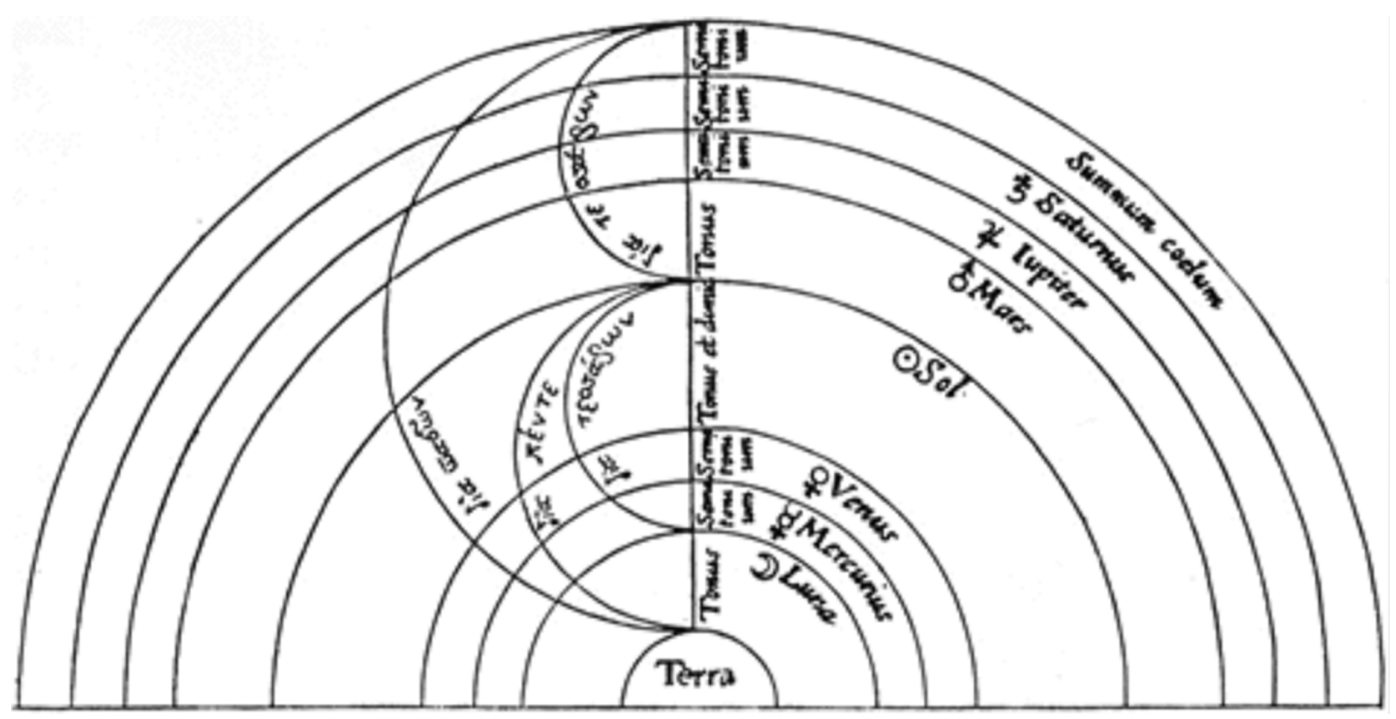

Fig. 2. The celestial spheres of the moon, the sun, the planets and the fixed stars.

Fig 2. Les sphères célestes de la lune, du soleil, des planètes et des étoiles fixes.

then it is the whole sentence which carries the meaning and that can also shift. At the more abstract level still of hermeneutics, then it is the narrative which takes precedence, as analyzed by narratology and storytelling [7]: the metaphor, la métaphore vive, thus helps re-define reality according to a particular discursive style (poetry, philosophy or mathematical modeling) and thus creates a metaphorical truth.

Among the most recent attempts at developing a "theory of everything", stands that of Ecology and of Industrial Ecology: indeed, the two complementary scientific disciplines ambition to project a holistic view of how the whole planet functions as a system. The point this article wants to make is that the models that are used in these disciplines are related to metaphors and images that echo the old Musica Universalis model. This may have occurred consciously or, more probably, unconsciously, because the number of models available for structuring human knowledge is finite [8].

\section{Sustainable development}

The first model proposed by scientific and industrial ecology is that of Sustainable Development or Sustainability, which is usually represented by a Venn diagram, cf. Figure 3. The concept, which had been slowing emerging [9], sprang into the limelight in the Brundtland report to the UN of 1987 [10] and was further popularized by the Earth Summit of Rio in 1992, where the Conventions on Climate Change [11] and on Biodiversity [12] were signed and the Agenda 21 program [13] was launched. The idea is that human affairs ought to be conducted in such a way that the planet would continue to care for future generations, and therefore, that resources would be preserved and the degradation of the environment would be checked. It is actually more a political roadmap for the governance of the planet than a statement that, indeed, development can continue at a quick pace and remain sustainable.

The Venn diagram's message is that the three domains of human activities represented by three circles, the economic, the social and the environmental, should somehow overlap in order to accommodate the constraints set by the other domains: the intersection between social and environmental defines what is bearable, that between economic and social what is equitable and that between economic and environmental, what is viable. Furthermore, what is at the same time bearable, equitable and viable is called sustainable. This representation proposes a coherent synthesis between the constraints of the three domains. Note that there are variants regarding the direction in which domains follow each other (clockwise or anticlockwise) and which one should sit on top, which sends subliminal messages about what actually is sustainability. Moreover, the intersection can be narrow or broad, suggesting that sustainability is a target which is either difficult or easy to reach. Presentations, where the 3 circles do not intersect, are never shown and rarely discussed, although there are cases when sustainability is not achievable!

The Venn presentation focuses on three conceptual domains shown as separate and independent and, therefore, which are seen as competing with each other: the economy is foreign to the preservation of the environment, it seems to say, while society has also its own rationale and drivers that match and accommodate the other domains' in limited ways only. Therefore, achieving sustainability requires tension and effort. The message is that of a narrow passage. Moreover, the representation does not say anything regarding what constitutes a possible match or compromise between the domains, and, as such, is not a very powerful model to explain what is happening, nor 

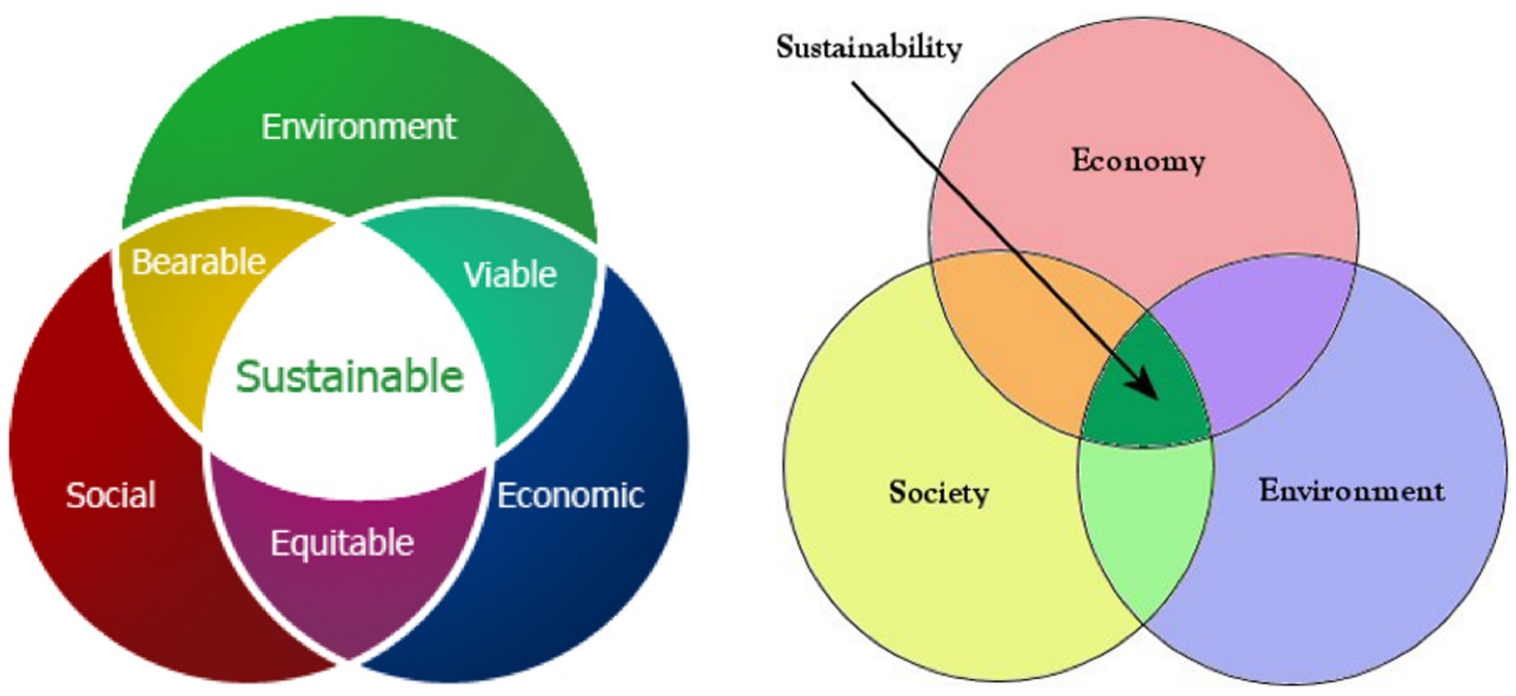

Fig. 3. Venn diagrams representations of Sustainable Development.

Fig 3. Diagrammes de Venn utilisés pour représenter le développement durable.

what ought to be done in the future. It is therefore a rather mute model, if one is interested in framing a strategy for the future.

The Venn representation of sustainability is based on circles but it does not have much to say about the music of these circles. The analogy with the old Musica Universalis approach is therefore weak and incomplete. It does not really represent how the world functions but rather seems to prescribe areas of cooperation, without getting into details: it is preaching about the need for change rather than proposing ways to manage the change.

There is another representation of sustainability based on the Pillar Model, which adopts the metaphor of a Greek or Roman classic temple as shown in Figure 4. It does not show any intersection of competing domains and therefore does not point out the difficulties to be tackled. It is rather a motivational model, stressing that the three pillars ought to support sustainability, which constitutes the tympanum of the construction, its achievement. It speaks to actionoriented people in political science or business management, rather than to scientists who would like to understand how the world ticks. It also posits coherence and cooperation between the Pillars, a harmony that echoes the Musica Universalis.

\section{The spheres of ecology}

Analyzing how the various domains of sustainability interact rather than intersect has been on the agenda of Ecology, which does have the broader scientific purpose of explaining how the world operates in all of its complexity.

Rather naturally, since we are talking about the Earth, we are back to spheres ${ }^{2}$, which mimic the shape of the planet.

\footnotetext{
2 "In the beginning, God created the heavens and the earth" (the Bible, Gen 1:1). Another obvious continuity from religious expression to metaphysical and physical inquiries.
}

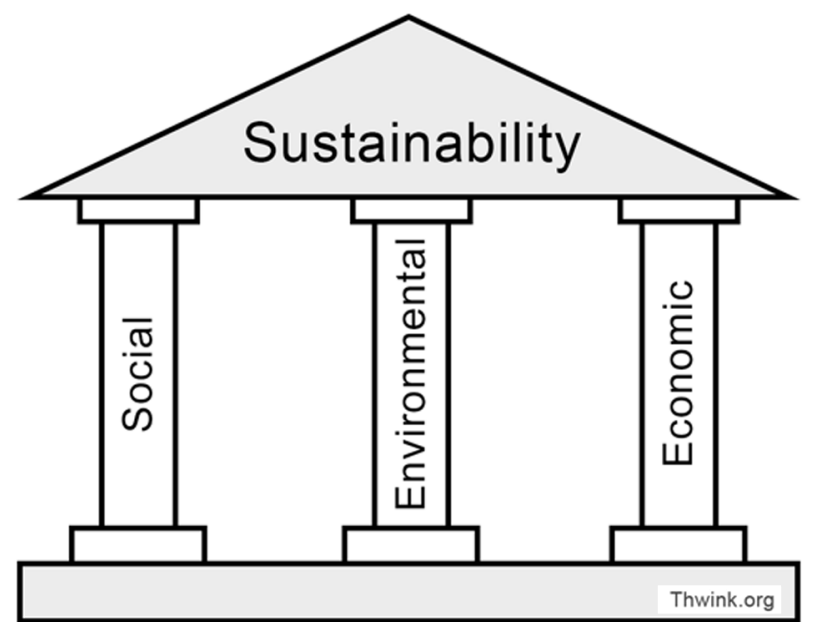

Fig. 4. The pillar representation of sustainable development.

Fig 4. La représentation en colonnes du développement durable.

A number of spheres have been conceptualized by Geography and then by Ecology and Industrial Ecology: - first, the planet itself, which is composed of the Lithosphere, the Geosphere ${ }^{3}$, the Atmosphere, the Hydrosphere and the Cryosphere. These are physical constructs originating from observations, but which do not require too much abstraction. The word sphere is used to designate both solid spheres and hollow spheres, like the lithosphere or the atmosphere, for example. Calling all of them spheres, however, stretches the word beyond its mathematical meaning as the hydrosphere and the cryosphere are located on a sphere, the lithosphere, but only in part of the world, and thus are subsets of hollow spheres;

\footnotetext{
${ }^{3}$ Lithosphere and Geosphere are used in subtly different ways by different disciplines, but we will consider them as synonymous for the purpose of the present discussion.
} 

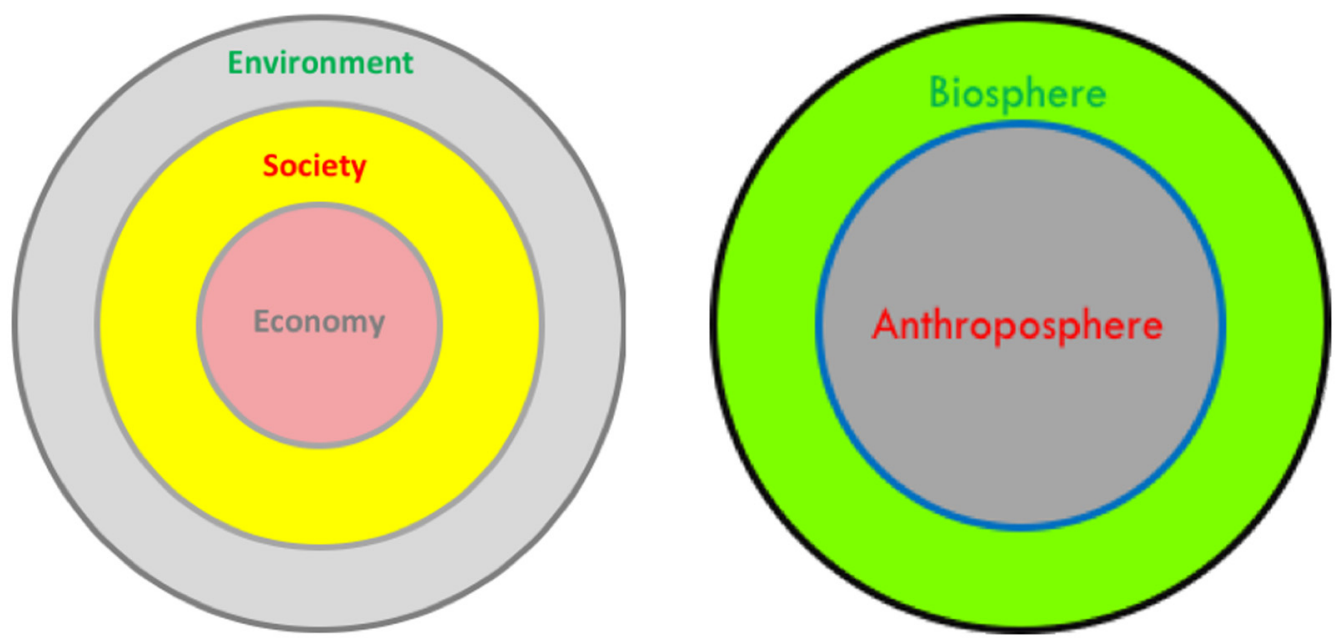

Fig. 5. Interconnection of the Ecological Spheres [16].

Fig 5. Plusieurs représentations des relations entre les sphères de l'écologie [16].

- the Hydrosphere actually contains all the water in the world, therefore the oceans and the sea, but also the streams and rivers, the underground water, either part of the hydraulic watershed or of the water tables but also deeper water, for example, in deep saline aquifers or in magmatic matter. The simplicity of the earlier definitions is now gone in favor of a more abstract vision of the set of water bodies present on the whole planet, near its surface, and, actually, inside other spheres, such as the aquifers enclosed in the lithosphere or the geosphere. The water embedded in living organisms is also part of the hydrosphere, which enormously increases its complexity. The hydrosphere is a three-dimensional patchwork, that percolate in all the sphere described in the previous list of spheres and in the next ones;

- the Biosphere is the set of living organisms present on Earth, on the lithosphere (plants, animals, bacteria, etc.), but also in the hydrosphere (fish and crustaceans, algae, etc.), the atmosphere (birds and flying insects) and even inside the lithosphere (life in the soil or in caves isolated from the ground). The biosphere is an even more fragmented patchwork than the hydrosphere, but it is globally organized around the surface of the planet and as such can be called a sphere;

- moving to an even greater level of complexity and of abstraction, one reaches the concept of the Anthroposphere, i.e. the set of people (thus a subset of the biosphere) and of their artifacts present on Earth. This is sometimes called Society and, more rarely today, Civilization. This includes women and men, adults and children, their homes, their offices, their industrial plants, their schools and courts of justice, infrastructures, and all artifacts in general. It includes people on the ground, in buildings, in trains, boats and planes, etc., as well as their animals in farms, homes (pets) or zoos;

- a subset of the Anthroposphere is called the Technosphere: it designates the most sophisticated (technological) artifacts made in the Anthroposphere and includes industrial plants, offices as well as the objects (consumption and investment goods) that are dispersed in the anthroposphere. Works of art are not usually considered as part of the technosphere and thus museums neither. Architecture blends technology and art and therefore is in an in-between limbo. Note that the technosphere contains objects, parts of which are dangerous and unfriendly to life, like the core of a nuclear reactor or the inside of a blast furnace;

- the level of abstraction can get even higher: one talks about the Econosphere, the sphere of the economy, or the Datasphere to designate the world of data, which has become recently more obvious with the craze about Big Data and the business created around the use of data. There is room also for a Cultural Sphere, an expression which is used in vernacular language but not yet formally in Ecology - even though Culture is part of the Ecosystem Services rendered by Biodiversity.

All these spheres interact, at very complex levels and at different space and time scales. They work together smoothly and, therefore, this constitutes a Harmony of these spheres.

A first exercise consists in looking for a match between the Sustainability model and the Ecology Sphere model. The Social Sphere of sustainability can be taken as the equivalent to the Anthroposphere. The Environmental Sphere encompasses both the Biosphere and the Atmosphere and it overlaps on the Geosphere. The Economic Sphere is embedded in the Anthroposphere, with overlaps on the other spheres. This leads to the diagrams of Figure 5: gone is the image of distinct and separate domains and of competing priorities represented in the Sustainability Venn diagram; society is part of the Biosphere, the new diagrams say, and so is the Anthroposphere. This is stating that the environment cannot be considered as an externality with regards to the Anthroposphere, as mainstream neoclassical economics still posits today, and also that the future of the Biosphere is now controlled by the Anthroposphere, given the size that society has assumed on the face of the Earth: it can therefore lead to a strong deterioration of the environment, or not, 
depending on policies to be followed in the future: sustainability is not a given, it is a possibility for the future, if the proper steps are taken in the proper direction.

\section{An harmony of the spheres of ecology?}

A second exercise consists in looking for what could impersonate the Harmony of the Spheres in the case of the ecology spheres. Harmony means relationships and, indeed, we will look at how spheres mix and overlap at their boundaries to explore these connections.

We will restrict the discussion however to materials and use examples from this area.

\subsection{The music of physics and thermodynamics}

In the beginning (in principio) is the music of physics, which plays at the core of what a modern scientist sees in nature, technology and society. This includes thermodynamics, which describes the relationships tying elements and items of the ecological spheres around the concept of equilibrium, a very deep and powerful notion which tackles an intrinsic feature of things, not simply the story telling of trajectories and dynamics (the State Functions of Thermodynamics).

Materials, which constitute the structure of all human artifacts, are mainly out of equilibrium with prevalent natural conditions (often called "room temperature conditions": temperature, pressure and chemical potentials). Materials are made (manufactured) using technology, thus in the anthroposphere and more precisely in the technosphere, and then are quenched in "room temperature" conditions. Technology therefore uses physical laws to create bubbles that are out of equilibrium with nature but which can remain in that state for long enough periods of time, commensurate with the time needed for using things, a concept related to the life cycle of a commercial product. This temporality is not commensurate with the natural characteristic times of geology and of life (evolution) and even more of cosmology.

\subsection{The Interface between the technosphere and the biosphere}

The technosphere is composed of the all the reactors, chemical, metallurgical and materials reactors, which populate the materials Industry of today and the Art and Craft workshops of the past, e.g. metal converters (steel, copper, nickel, etc.) but also power plants of all kinds or modern bio-refineries and, prior to that, bloomeries or forges. They are used to make materials which do not exist in nature - for most of them. By playing with the equilibria of thermodynamics that are prevalent at different temperatures, they buy mankind time to use artifacts for as long as they are needed. Note also that equilibria are not always in place, especially at lower temperatures, and that kinetics (i.e. time again) and catalysts take over to help produce these artifacts and some of the materials that they are made of. Note also, incidentally, that Life (the metabolism of biochemistry) is also completely driven by kinetics and catalysts (enzymes), not by equilibrium.
Equilibria with nature take over artifacts, eventually, and drive them back to thermodynamic equilibrium. This is called for example corrosion, oxidation or chemical, sometimes electrochemical attack in the case of materials, metals of course but also cultural heritage materials, mostly wood and stones. The temporality of this "reversal to nature" is fairly slow and decay takes place at a pace that is commensurate with how carefully artifacts are maintained, for example thanks to anti-corrosion technologies or to repair and reconstruction practices (cultural heritage). These phenomena are taking place at the very interface of materials and atmosphere. This is nature intruding.

Thus, the Biosphere (and/or the Atmosphere, the Hydrosphere) eats up at the physical substrate of the Anthroposphere and of the Technosphere to make it disappear, dissolve back into nature itself. Society, on the other hand, i.e. the Anthroposphere, is fighting hard to ensure its sustainability and secure its future, at least to some extent, as the transitory nature of artifacts is part of the vision that society has of itself, which includes innovation and change, at the deep level of scientific or technological paradigm shifts or at the shallower one of the permanent reinvention of products by marketing departments (including, sometimes, programmed obsolescence?).

More generally, the Anthroposphere is rejecting substances to the biosphere, the atmosphere or the hydrosphere, which industry calls air, water or soil emissions but vernacular language calls more straightforwardly pollution. This is the Anthroposphere intruding into Nature, the very opposite of corrosion. This can be a small effect, with mild consequences, but, more recently, the size of the Anthroposphere has become so large that the interaction is becoming global and affects the very equilibria of nature itself (climate, biodiversity, etc.) to the point that the existence of mankind might be jeopardized in the long term.

We have the Little Night Music of Mozart on the one hand, although it is enduring and persistent like the Bolero of Ravel, but, on the other hand we have the roars of Wagner's operas, for example Götterdämmerung, and maybe the noise of a "force 5 " hurricane.

There is another interface between Biosphere and Anthroposphere, which lies between Life and anthropogenic emissions, thus the Anthroposphere, and which is described by Toxicology and Health issues, as in Health and Safety on the work place or in Public Health. Thus mankind, being part of both the Biosphere and of the Anthroposphere, ends up cannibalizing itself when technology runs awry and starts attacking the environment: man, at this level, is more a part of nature than of the technological society.

What may be harmful to mankind, in this case pollution, may also be harmful to Nature, the Environment or the non-human part of the Biosphere. The discipline that explores these phenomena is called Ecotoxicology. The biosphere is represented by living organisms but also by ecosystems, a higher order of organization of Life: pollution may be harmful to individual living organisms but also to their "society", i.e. to ecosystems. This, again, is an impregnation of Nature by the Anthroposphere, a complex interaction that still needs more research and 
more societal awareness: it is a kind of holistic music, that diffuses far away from the instruments which play it (like the smokestacks of a power plants or an industrial plant) and which resonate at the various scales of ecosystems.

The $4^{\text {th }}$ movement of the Pastoral Symphony of Beethoven could illustrate that.

\subsection{The interface between technosphere and geosphere}

The Anthroposphere harvests resources in terms of raw materials and energy, from the Geosphere, like metallic ores, minerals from quarries, oil, natural gas or coal, and Nature in general: this includes renewable energy sources (wind, solar, ocean, geothermal), biomass for industrial and heating applications and gravity (hydropower). This has been going on ever since modern man evolved from earlier homo species. For millions of years, this did not interfere with Nature, the Planet or the Biosphere, whichever way it is named, until recently, maybe one hundred years ago, when the scale of human contribution to the planetary energy balance caused subtle but visible changes in the climate and on the equilibria that rule the biosphere: this includes the on-going $6^{\text {th }}$ extinction of living species.

The operational answer that the Anthroposphere is proposing to these serious matters is to deeply change the Technosphere in order to let the Biosphere remain compatible with life as we know it, i.e. with the continuing existence of man on Earth. In order to survive, the Anthroposphere must therefore change at the level of its technologies (the Technosphere), by changing its energy base to renewable energy and by organizing on the principle of the circular economy. A demographic moderation, which seems under way, would ensure that these transitions (energy and ecology transitions) indeed deliver what is expected in terms of ushering in a truly sustainable world. This also means that artifacts should be designed in ways that are lean, agile and frugal, thus ensuring longer lives of equipment and consumer products, allowing for reuse and remanufacturing and for proposing design solutions of an artifact that call on less numerous elements, especially those that might turn rare and scarce (Critical Raw Materials, CRMs).

A piece of music, which would represent all these phenomena in their furor and complexity, might be the Rite of Spring by Igor Stravinsky.

Scientists have been careful not to indulge in global theories and holistic approaches, which try to embrace too much. This is true in physics, even if an emblematic field looks for a true Theory of Everything, but this is actually confined to high energy physics concepts and does not try to tackle all human knowledge and activities. This is also true in History and even more so in Prehistory [14]. Social Sciences and Philosophy have probably gone the furthest in the direction of deconstructing previous knowledge and mainstream methods and in questioning modernity. The only scientific field, where holistic and ambitious approaches are the norm, is Life Cycle Analysis (LCA). It tries to combine all the musics we have been mentioning, i.e. all the interactions between the various spheres of Ecology (cf. the presentations to SAM conferences $[15,16]$ ).

\section{Conclusions}

We have described connections between the spheres of Ecology and of Industrial Ecology that constitute a complex harmony. This is not as simple as the Greek presented it, when they proposed a metaphor between the music of a lyre and the motion of the planets in the sky. But it is also the story of the coherence of the phenomena which have been taking place on Earth, since the very beginning of the Planet, at least as soon as life appeared, 4.5 billion years ago. They have preserved the Planet, until now, although it went through dramatic and traumatic events, which can be characterized by major biodiversity extinctions: the planet went on, life went on, but species died and were reborn into new ones.

These enduring phenomena can be imagined as being balanced according to subtle rules, which represent the Harmony of Nature and, to paraphrase Aristotle, "because one believes being authorized to conclude that such grand schemes at the scale of the History of the Universe cannot pass without making any intense noise", a Music of the Ecological Spheres. That music today is told by using the language of modern science and of the mathematics that comes along with it, but the more mundane story telling of Philosophy, Social Sciences, Art and Literature, including Music, is also at work, not to forget the stories that people tell in everyday life.

\section{Appendix 1}

"Contemporaneously with these philosophers and before them, the so-called Pythagoreans, who were the first to take up mathematics, not only advanced this study, but also having been brought up in it they thought its principles were the principles of all things. Since of these principles numbers are by nature the first, and in numbers they seemed to see many resemblances to the things that exist and come into being-more than in fire and earth and water (such and such a modification of numbers being justice, another being soul and reason, another being opportunity-and similarly almost all other things being numerically expressible); since, again, they saw that the modifications and the ratios of the musical scales were expressible in numbers;-since, then, all other things seemed in their whole nature to be modelled on numbers, and numbers seemed to be the first things in the whole of nature, they supposed the elements of numbers to be the elements of all things, and the whole heaven to be a musical scale and a number. And all the properties of numbers and scales which they could show to agree with the attributes and parts and the whole arrangement of the heavens, they collected and fitted into their scheme; and if there was a gap anywhere, they readily made additions so as to make their whole theory coherent. E.g. as the number 10 is thought to be perfect and to comprise the whole nature of numbers, they say that the bodies which move through the heavens are ten, but as the visible bodies are only nine, to meet this they invent a tenth-the 'counter-earth'." [17] 


\section{References}

1. T. Reinach, La musique des sphères, Rev. études grecques $\mathbf{1 3}$ (55), 432-449 (1900). DOI : 10.3406/reg.1900.6021.

2. I. Arel, D.C. Rose, T.P. Karnowski, Deep machine learning A new frontier in artificial intelligence research, IEEE Comput. Intel. Mag. 13-18 (November 2010)

3. D. Proust, L'harmonie des sphères, Science ouverte, Seuil, Paris, 2001

4. S. Norman-Haignere, N.G. Kanwisher, J.H. McDermott, Distinct cortical pathways for music and speech revealed by hypothesis-free voxel decomposition, Neuron. 88(6), 12811296 (2015)

5. J-P. Birat, Modélisation et conduite des processus sidérurgiques, Rev. Metal.-CIT 1347-1387 (1997)

6. P. Ricoeur, La métaphore vive, Seuil, Paris, 1975

7. C. Salmon, Storytelling, la machine à raconteur des histoires et à formater l'esprit, La Découverte, Paris, 2008

8. J. Friedel, Personal communication, ca. 1990 and Sur l'usage des modèles en métallurgie, Rev. Metal.-CIT, 893-900 (2004)

9. K. Bartenstein, Les origines du concept de développement durable, Rev. Jurid. Environ. 3, 289-297 (2005)
10. G.H. Brundtland, Our Common Future, Report of the World Commission on Environment and Development, UN, A/42/ 427, 4 August 1987

11. United Nations Framework Convention on Climate Change, https://unfccc.int/essential_background/convention/ items/6036.php

12. United Nations Convention on Biological Diversity, https:// www.cbd.int

13. United Nations, Earth Summit: Agenda 21, The United Nations program of action from Rio, 300 pp, 23 April, 1993, https://sustainabledevelopment.un.org/outcomedocu ments/agenda21

14. J.-P. Birat, Society and Materials: how it all started, a few million years ago, Matériaux et Techniques 104(6/7), 1-19 (2016)

15. SAM conferences, http://www.sovamat.org/

16. J.-P. Birat, A. Declich, S. Belboom, G. Fick, J.-S. Thomas, M. Chiappini, Society and Materials, a series of regular seminars based on a dialog between soft and hard sciences, Metal. Res. Technol. 112, 501 (2015). DOI: 10.1051/metal $/ 2015024$.

17. Aristotle, Metaphysics, 350 BCE, translated by W.D. Ross, MIT Classics Library. http://classics.mit.edu/Aristotle/ metaphysics.html.

Cite this article as: Jean-Pierre Birat, Musica Universalis or the Music of the Spheres, Matériaux \& Techniques 105, 509 (2017) 